\title{
PREVENTION OF SARS-COV-2 CORONAVIRUS SPREAD AT THE AUSCHWITZ- BIRKENAU STATE MUSEUM IN POLAND, THE MOST VISITED MEMORIAL SITE IN THE WORLD, DURING THE COVID-19 PANDEMIC
}

\author{
ZAPOBIEGANIE ROZPRZESTRZENIANIU SIĘ KORONAWIRUSA SARS-COV-2 \\ W PAŃSTWOWYM MUZEUM AUSCHWITZ-BIRKENAU W POLSCE, NAJCZĖŚCIEJ \\ NA ŚWIECIE ODWIEDZANYM MIEJSCU PAMIĘCI, PODCZAS PANDEMII COVID-19
}

\author{
${ }^{1}$ Auschwitz-Birkenau State Museum, Więźniów Oświęcimia 20, Poland \\ ${ }^{2}$ Sanitary-Epidemiological Station, Kraków, Poland \\ ${ }^{3}$ Medical University of Lublin, The Chair and Department of Oral Surgery, Medical University of Lublin, \\ 'Państwowe Muzeum Auschwitz-Birkenau w Oświęcimiu, Polska \\ ${ }^{2}$ Wojewódzka Stacja Sanitarno-Epidemiologiczna w Krakowie, Polska \\ ${ }^{3}$ Uniwersytet Medyczny w Lublinie, Katedra i Zakład Chirurgii Stomatologicznej, Polska
}

\begin{abstract}
INTRODUCTION. At the Auschwitz-Birkenau State Museum (A-BSM) actions have been undertaken to effectively protect employees and minimise risk of SARS-CoV-2 coronavirus spreading from the beginning of the COVID-19 epidemic.

AIM OF THE ARTICLE. The aim was to present the actions, instructions and procedures introduced at the A-BSM to provide information how to deal with pandemic caused by the SARS-CoV-2 coronavirus in institutions taking care of cultural heritage before and after closure of the Museum for visitors and after reopening.

MATERIALS AND METHODS. The described activities were developed at the Museum by a specially established Expert Team.

RESULTS. Groups of employees and places in which they were most exposed to contact with visitors and, as a consequence, at the highest risk of getting infected, were characterised. The employees were provided with personal protective equipment, and at the Museum site, devices essential for maintaining the microbiological cleanliness of the rooms, were placed. In the next stage, instructions and procedures for particular groups of employees were prepared. Visitors were educated about the need of taking precautions and were allowed to disinfect in several places at the Memorial Site. Steps to reduce attendance at this time has also been taken. Procedures for employees of the A-BSM were developed in such way that they can also be used after reopening of the Museum for visitors.

CONCLUSIONS. The actions which ensured the microbiological safety of the A-BSM employees, brought satisfying results. In more than 21 days after closing of the Museum for visitors, no cases of SARS-CoV-2 infection or COVID-19 were found among employees, despite a very high threat.
\end{abstract}

Keywords: SARS-CoV-2, COVID-19, Auschwitz-Birkenau State Museum, biosafety procedures, disinfection

\section{STRESZCZENIE}

WSTĘP. Od początku epidemii COVID-19 w Państwowym Muzeum Auschwitz-Birkenau (PMA-B) podejmowano działania mające na celu skuteczną ochronę pracowników i zminimalizowanie ryzyka rozprzestrzeniania się koronawirusa SARS-CoV-2.

CEL PRACY. Celem było przedstawienie działań, instrukcji i procedur zastosowanych w PMA-B, aby przekazać informacje, w jaki sposób można postępować w sytuacji pandemii wywołanej koronawirusem SARSCoV-2 w jednostkach dbających o dziedzictwo kulturowe przed i po zamknięciu Muzeum dla odwiedzających oraz po ponownym otwarciu. 
MATERIALY I METODY. Opisane działania były opracowywane w Muzeum przez specjalnie powołany Zespół Ekspertów.

WYNIKI. Scharakteryzowano grupy pracowników i miejsca, w których są oni najbardziej narażeni na kontakt z odwiedzającymi, a w konsekwencji obarczeni największym ryzykiem zakażenia. Zaopatrzono pracowników w środki ochrony osobistej, a na terenie Muzeum umieszczono urządzenia służące do utrzymania czystości mikrobiologicznej pomieszczeń. Sporządzono instrukcję i procedury postępowania dla poszczególnych grup pracowników. Odwiedzających edukowano o konieczności zachowania środków ostrożności i umożliwiono dezynfekcję w kilku miejscach na terenie Miejsca Pamięci. Muzeum podjęło również kroki w celu zmniejszenia frekwencji w tym czasie. Procedury postępowania dla pracowników PMAB zostały opracowane w taki sposób, aby można było je wykorzystać również po przywróceniu ruchu odwiedzających.

WNIOSKI. Wdrożone w PMA-B działania, zapewniające bezpieczeństwo mikrobiologiczne pracowników przyniosły bardzo dobre rezultaty, tj. po ponad 21 dniach od zamknięcia Muzeum dla odwiedzających, nie stwierdzono żadnych przypadków zakażenia koronawirusem SARS-CoV-2 ani zachorowania na COVID-19, mimo bardzo dużego zagrożenia.

Słowa kluczowe: SARS-CoV-2, COVID-19, Państwowe Muzeum Auschwitz-Birkenau, procedury bezpieczeństwa mikrobiologicznego, dezynfekcja

\section{INTRODUCTION}

Auschwitz-Birkenau in Oświęcim, a former German Nazi Concentration and Extermination Camp is the largest and most visited Memorial Site in the world. During the 74th anniversary of the liberation of the camp in January 27, 2019, the director of the Auschwitz-Birkenau State Museum (A-BSM) in Oświęcim, Poland, dr Piotr Cywiński said "Ramp does not equal platform. Number does not equal name. Segregation or selection does not equal choice. Barracks does not equal building." (1). People should respect each place and object that remained after World War II in this place. This is possible thanks to the people who work in the A-BSM. They both care for this place and educate visitors from all over the world. Therefore, at the time of epidemic, and later pandemic, caused by Severe Acute Respiratory Syndrome coronavirus 2 (SARS-CoV-2), protection of the employees of the Museum, became so important and a priority for the Directorate.

Every day the A-BSM is visited by up to 8000 people. The service is provided by 340 educators, who accompany groups of visitors during a minimum 3.5hour long visit. The remaining 440 employees deal with the conservation, administration and protection of the Museum site.

According to the Situation Reports published by World Health Organization (WHO), the epidemic caused by SARS-CoV-2 coronavirus began in the Chinese city of Wuhan in December 2019 (2) and quickly turned into the pandemic. The first cases of COVID-19 acute respiratory disease among Europeans that appeared in France, aroused concern, because it meant that the coronavirus was beginning to spread in Europe (3). The next country, where an infected person was diagnosed, was Germany (4). A month

\section{WSTĘP}

Były Niemiecki Nazistowski Obóz Koncentracyjny i Zagłady Auschwitz-Birkenau w Oświęcimiu jest największym i najliczniej odwiedzanym Miejscem Pamięci na świecie. Dyrektor Państwowego Muzeum Auschwitz-Birkenau, dr Piotr Cywiński, podczas przemówienia z okazji 74 rocznicy wyzwolenia obozu, w dniu 27 stycznia 2019 roku powiedział, iż w tym miejscu „Rampa to nie to samo, co peron. Numer to nie to samo, co imię. Segregacja czy selekcja to nie to samo, co wybór. Barak to nie to samo, co budynek." (1). Tutaj należy zachować szacunek do każdego miejsca i obiektu, który pozostał po II wojnie światowej. Jest to możliwe dzięki ludziom, którzy tutaj pracują, pielęgnują i dbają o to miejsce, a także edukują odwiedzających z całego świata. Dlatego w sytuacji wystąpienia epidemii, a później pandemii wywołanej koronawirusem zespołu ostrej niewydolności oddechowej 2 (SARS-CoV-2) ważna i priorytetowa dla Dyrekcji stała się ochrona pracowników Muzeum.

Każdego dnia PMA-B odwiedza nawet do 8000 osób. Obsługę zapewnia 340 Edukatorów, którzy towarzyszą grupom zwiedzających podczas minimum 3.5-godzinnej wizyty. Pozostali pracownicy w liczbie 440 osób zajmuje się konserwacją, administrowaniem oraz ochroną Muzeum.

Według Raportów Sytuacyjnych Światowej Organizacji Zdrowia (WHO), epidemia wywołana przez koronawirusa SARS-CoV-2, rozpoczęła się w chińskim mieście Wuhan w grudniu 2019 roku (2) i szybko przerodziła się w pandemię. Pierwsze przypadki ostrej choroby układu oddechowego COVID-19 wśród Europejczyków, które pojawiły się we Francji wzbudziły niepokój, ponieważ oznaczało to, iż koronawirus zaczyna się rozprzestrzeniać w Europie (3). Następnym krajem, w którym zdiagnozowany został zakażony 
later, approximately 400 cases of COVID-19 were already reported in Italy (5). The first case of a person infected with the coronavirus in Poland was confirmed on 4th March 2020. In the Situation Report no. 51 of 11th March 2020, WHO announced that COVID-19 can be characterised as a pandemic (6). The same report showed, inter alia, that in total 80955 cases of SARS-CoV-2 infection were confirmed and 3162 people died in China, there were 7755 cases and 60 deaths in South Korea, 568 patients were infected and 12 of them died in Japan, and 166 patients got the COVID-19 in Singapore. The coronavirus was also spreading quickly in European countries, and until 11th March 2020 the following number of cases and deaths were reported: Italy 10149 and 631, France 1 774 and 33 and Germany 1296 and 2, respectively.

From the beginning of the coronavirus epidemic, there were doubts, on how to effectively protect the employees and limit the spreading of SARS-CoV-2 coronavirus within the Museum, especially in places, where it is not possible to keep recommended distance between people. Due to the specificity of this place, the huge number of visitors from all around the world, the need to protect all people working at the Museum, and also the lack of central regulations and guidelines, the A-BSM developed its own strategy of the action and then implemented it.

\section{AIM OF THE WORK}

The aim was to present the actions, instructions and procedures introduced at the A-BSM, to provide information, how to deal with pandemic caused by the SARS-CoV-2 coronavirus in institutions taking care of cultural heritage before and after closure of the Museum for visitors and after reopening.

\section{MATERIALS AND METHODS}

In this study data from the registers of Visitor Service Department, concerning the number of A-BSM visitors and countries from which they came in the period from 20.02.2020 to 11.03.2020, were used. To assess the epidemical threat associated with people coming to the Museum from various places in the world, the reports presented by Polish Chief Sanitary Inspectorate (GIS) and WHO were used. The described activities were developed by a specially established Expert Team. To determine the places in which the highest risk of infection occurs and create a risk map, members of the Team followed the visiting route. Personal protective equipment and contactless fumigation disinfectants were selected based on their effectiveness and availability in Poland during the epidemic and pandemic. człowiek, były Niemcy (4). Miesiąc później, we Włoszech było już około 400 przypadków zachorowań wywołanych przez koronawirusa SARS-CoV-2 (5). Dnia 04.03.2020 potwierdzono pierwszy przypadek zachorowania na COVID-19 w Polsce. W Raporcie Sytuacyjnym nr 51 z dnia 11.03.2020 r. WHO ogłosiło, że COVID-19 charakteryzuje się jako pandemia (6). W tym samym raporcie wykazano między innymi, że w Chinach potwierdzono 80955 przypadków zakażonych SARS-CoV-2 i 3162 osób zmarło, w Korei Południowej było 7755 przypadków i 60 zgonów, w Japonii 568 pacjentów było zakażonych z tego 12 zmarło, a w Singapurze 166 pacjentów miało COVID-19. Również w krajach europejskich rozprzestrzeniał się koronawirus i tak stan na dzień 11.03.2020 wynosił: Włochy 10149 zakażeń i 631 zgonów, Francja 1774 i 33 oraz Niemcy 1296 i 2, odpowiednio.

Od początku epidemii wywołanej przez SARS-CoV-2, pojawiały się wątpliwości, w jaki sposób skutecznie zabezpieczyć pracowników oraz ograniczyć rozprzestrzenianie się koronawirusa na terenie Muzeum, szczególnie w miejscach, w których nie jest możliwe zachowanie zalecanego dystansu między osobami. Z uwagi na specyfikę miejsca, ogromną liczbę zwiedzających z całego świata, konieczność ochrony wszystkich osób pracujących w Muzeum, a także brak odgórnych regulacji i wytycznych, PMA-B opracowało własną strategię działań, a następnie ją realizowano.

\section{CEL PRACY}

Celem było przedstawienie działań, instrukcji i procedur zastosowanych w PMA-B, aby przekazać informacje, w jaki sposób można postępować w sytuacji pandemii wywołanej koronawirusem SARSCoV-2 w jednostkach dbających o dziedzictwo kulturowe przed i po zamknięciu Muzeum dla odwiedzających oraz po ponownym otwarciu.

\section{MATERIALY I METODY}

W niniejszym badaniu wykorzystano dane z rejestrów Działu Obsługi Odwiedzających, dotyczące liczby odwiedzających PMA-B i krajów, z których przybyli w okresie od 20.02.2020 do 11.03.2020. Do oceny zagrożenia epidemicznego związanego z ludźmi przybywającymi do Muzeum z różnych miejsc na świecie wykorzystano raporty przedstawione przez Główny Inspektorat Sanitarny (GIS) i WHO. Opisane działania zostały opracowane przez specjalnie powołany Zespół Ekspertów. Aby określić miejsca, w których występuje największe ryzyko infekcji i stworzyć mapę ryzyka, członkowie zespołu podążali trasą zwiedzania. Środki ochrony indywidualnej i bezdotykowe fumigacyjne środki dezynfekujące zostały wybrane na podstawie 


\section{RESULTS}

2.32 million people from all around the world visited the Auschwitz Memorial and Museum in 2019. The attendance in the beginning of 2020, in terms of days and months, was at a similar level. However, the information about the ongoing epidemic influenced the number of visitors. The increasing number of cases of SARS-CoV-2 coronavirus infections in the world has led, on 11th March 2020, to the need to make a government decision to close all cultural institutions in Poland, including the A-BSM, from the next day. Nevertheless, the actions to ensure safety of the Museum employees and protect them against infection were already undertaken 3 weeks earlier, due to the awareness that visitors coming from countries, in which outbreaks of the coronavirus were reported, may become a source of infection for people working in the A-BSM, who contact them. Fig. 1 shows the total number of 101619 people visiting the A-BSM from different countries by days when the visits took place, within 3 weeks before the Museum closing (20.02.202011.03.2020). A particular attention was paid to countries which were indicated in announcements prepared by GIS, based on the data presented by the European Center for Disease Prevention and Control (ECDC) and WHO, as regions at high risk of the coronavirus infections (7-11). Approximately 9302 people came from these countries, what constituted $9.15 \%$ of all visitors (Tab. I). Every day the number of people from these countries ranged from 149 to 865, what corresponded to $3.23 \%-15.80 \%$ of all visitors. At analysed time, fewer people came from the Asian countries affected by the epidemic: China, Hong Kong, Japan, Republic of Korea, Singapore and Taiwan (918 people in total for 3 weeks) than from European ones: France, Germany and Italy (8 384 people). Moreover, over a dozen of groups from Lombardy (the region in Italy, where the coronavirus spread the most in Europe) visited the Museum at that time. Iran, Thailand and Vietnam were also indicated by GIS as countries at high risk of the coronavirus infections, but no citizen of these countries visited the A-BSM during the three analysed weeks.

The current analyses of visitors indicated that there could be a very high epidemic threat to people working at the A-BSM. Consequently, an Expert Team of few people, including Epidemiologist, Directorate, representatives of the Visitor Service, Educators, Museum Security, Administration and OHS specialist, was formed. It was found that the Team members will meet each day to develop a strategy of the action. The Team was monitoring phases of the coronavirus spreading in the world and in Poland as well, and ich skuteczności i dostępności w Polsce w czasie epidemii i pandemii.

\section{WYNIKI}

Miejsce Pamięci i Muzeum Auschwitz odwiedziło w 2019 roku 2,32 miliona osób z całego świata. Frekwencja na początku roku 2020 w przeliczeniu na dni i miesiące kształtowała się na podobnym poziomie, jednak informacje ze świata o panującej epidemii wpłynęły na zmianę liczby odwiedzających. Narastająca liczba przypadków zakażeń koronawirusem SARS-CoV-2 na świecie doprowadziła 11 marca 2020 do konieczności podjęcia rządowej decyzji o zamknięciu od dnia następnego wszystkich placówek kultury w Polsce, w tym PMA-B. Jednak działania w celu zapewnienia bezpieczeństwa i ochrony przed zakazeniem pracownikom Muzeum były podejmowane już 3 tygodnie wcześniej, z uwagi na świadomość, iż osoby przybywające z krajów, w których zostały odnotowane ogniska koronawirusa, mogą stać się źródłem zakażenia dla osób z PMA-B mających kontakt z odwiedzającymi. Na ryc. 1 przedstawiono ogólną liczbę 101619 osób odwiedzających PMA-B z podziałem na różne kraje oraz dni, w których następowało zwiedzanie, w okresie 3 tygodni przed zamknięciem Muzeum (20.02.2020-11.03.2020). Szczególną uwagę zwrócono na kraje, które były wskazywane w komunikatach opracowywanych przez GIS, na podstawie danych European Centre for Disease Prevention and Control (ECDC) oraz WHO, jako regiony o wysokim ryzku zakażenia się koronawirusem (7-11). Z tych krajów przyjechało około 9302 osób, co stanowiło 9,15\% wszystkich odwiedzających (Tab. I). Liczba osób z tych krajów codziennie wahała się od 149 do 865 , co odpowiadało $3,23 \%$ - 15,80\% ogółu zwiedzających. W tym czasie mniej osób przyjechało z dotkniętych epidemią krajów azjatyckich: Chin, Hong Kongu, Japonii, Republiki Korei, Singapuru i Tajwanu (przez 3 tygodnie było ich 918 osób), niż z europejskich: Francji, Niemiec i Włoch (8 384 osób). Muzeum w tym czasie odwiedziło również kilkanaście grup z Lombardii (regionu Włoch, gdzie koronawirus rozprzestrzeniał się w największym stopniu na terenie Europy). GIS wskazał również Iran, Tajlandię i Wietnam jako kraje o wysokim ryzyku zakażenia się koronawirusem, jednak żaden obywatel tych krajów nie odwiedził PMA -B w okresie analizowanych 3 tygodni.

Bieżąca analiza odwiedzających osób wskazywała, że mogło wystąpić bardzo duże zagrożenie epidemiczne dla pracowników PMA-B. W związku z tym utworzono Zespół Ekspertów składający się z kilku osób, w tym Epidemiologa, Dyrekcji, przedstawicieli Obsługi Odwiedzających, Edukatorów, Straży Muzealnej, Administracji i specjalisty ds. BHP. Stwierdzono, że 

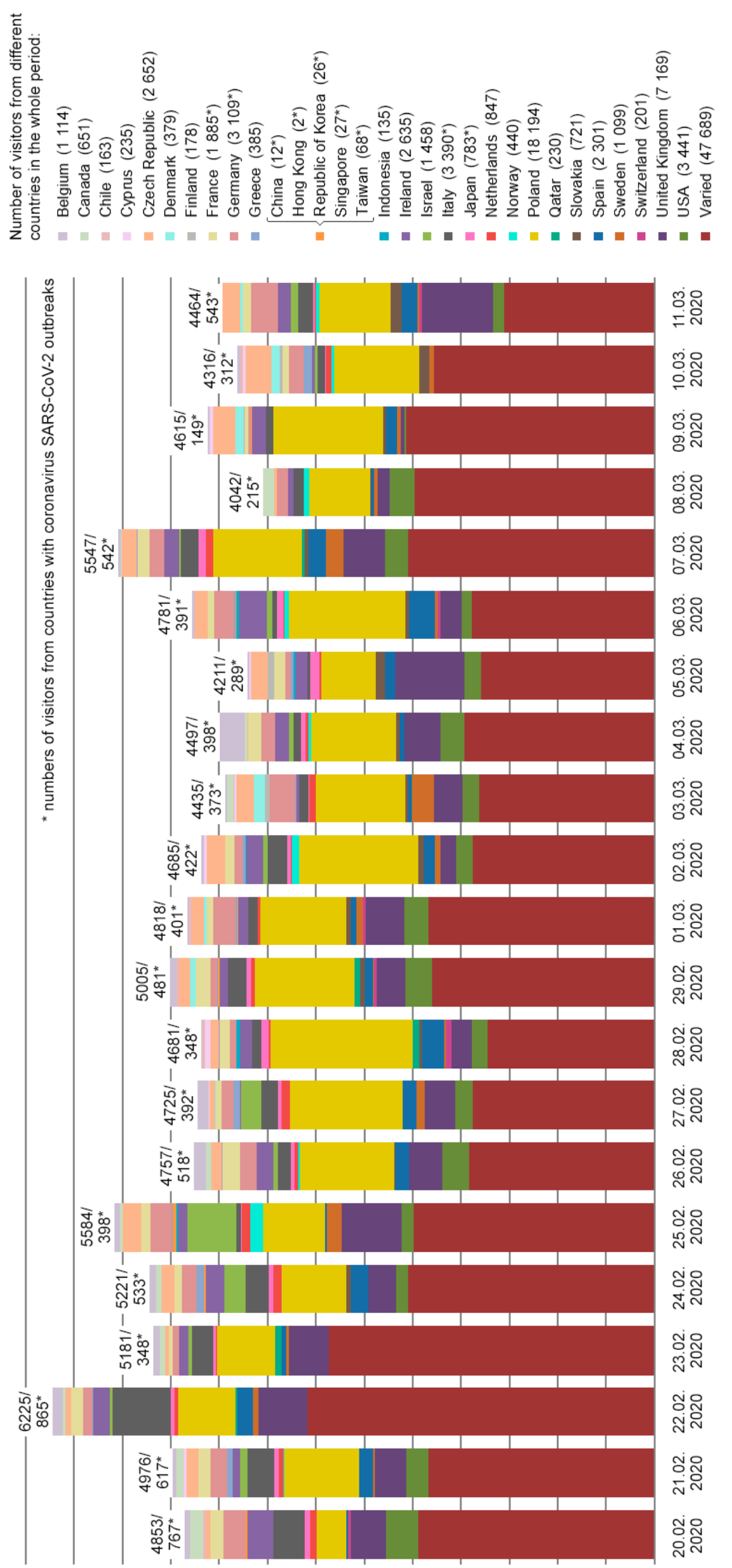

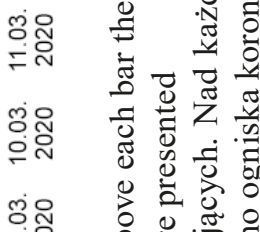

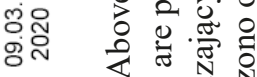
รูำ

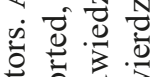

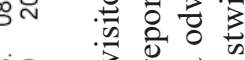

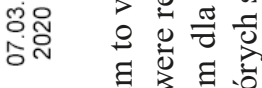
ก่ำ 言 母ั

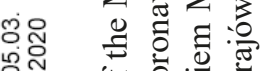
ยั่

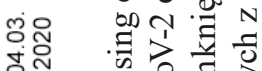
ชं के है กำ 0

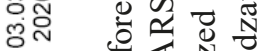
ल० 8 के

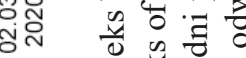
ํㅜ

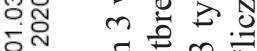
ธั $\Xi m^{\prime *}$

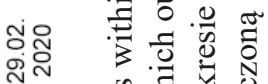
กั่

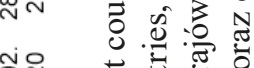

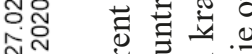

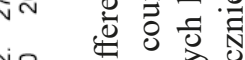

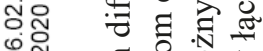
ถูกิ ช่ำ

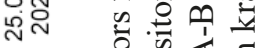
ส่ำ ปักิ $>$ क $\sum \dot{\overline{0}} \overline{0}$

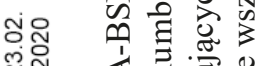
กั่

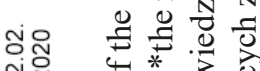
สู่ ส่ำ สิ

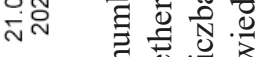

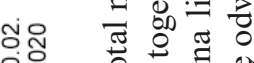
包宫 N

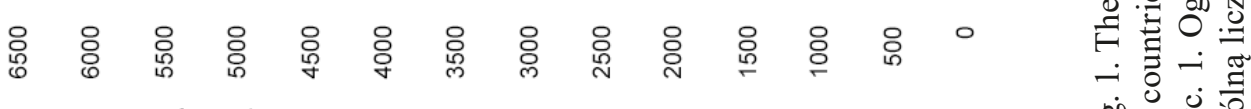

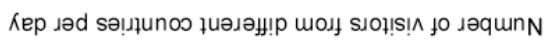

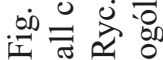




\begin{tabular}{|c|c|c|c|c|c|c|c|c|c|c|}
\hline$\underset{\mathbb{N}}{\mathbb{N}}$ & 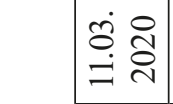 & 0 & $\infty$ & $\stackrel{\widetilde{N}}{\sim}$ & 0 & İ & $\approx$ & 0 & 0 & 0 \\
\hline$\stackrel{\circ}{\circ}$ & 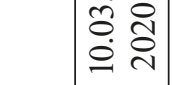 & 0 & $?$ & $\hat{n}$ & $\sim$ & $\stackrel{n}{x}$ & $\infty$ & 0 & 0 & 0 \\
\hline$\frac{0}{0}$ & 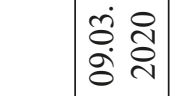 & 0 & ले & 尺 & 0 & $\mathbb{N}$ & 0 & 0 & 0 & $\sim$ \\
\hline 3 & 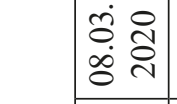 & 0 & 6 & $\stackrel{\infty}{\varrho}$ & 0 & 으 & 0 & 0 & 0 & 0 \\
\hline : & 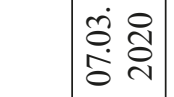 & 0 & $\grave{\Xi}$ & $\curvearrowleft$ & 0 & $\stackrel{\widetilde{O}}{\sim}$ & $\hat{\imath}$ & 0 & 0 & 0 \\
\hline $\begin{array}{l}\text { N } \\
\text { W } \\
0 \\
0\end{array}$ & 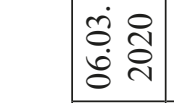 & 으 & $\bar{\sigma}$ & ๕ั & 0 & f & 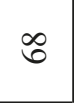 & 0 & 0 & 0 \\
\hline \begin{tabular}{l}
$\tilde{\Xi}$ \\
] \\
\multirow{I}{*}{}
\end{tabular} & 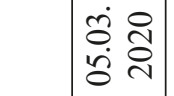 & 0 & $\Xi$ & $i n$ & 0 & $\tilde{\sim}$ & ¿゙ & 0 & 0 & 0 \\
\hline 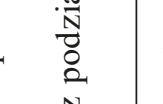 & 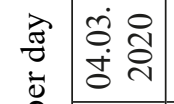 & 0 & సે & $\stackrel{\text { Iq }}{I}$ & 0 & $\cong$ & $\bar{n}$ & 0 & 0 & 0 \\
\hline 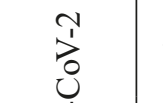 & 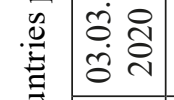 & 0 & 0 & $\underset{\Delta}{\Delta}$ & 0 & $n$ & $\nabla$ & 0 & 0 & 0 \\
\hline 点 & 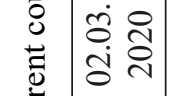 & 0 & $\tilde{\varrho}$ & চ & 0 & $\hat{a}$ & $\tilde{m}$ & 0 & $\nabla$ & 0 \\
\hline 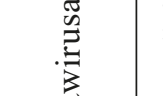 & 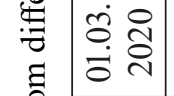 & 0 & $\approx$ & $\widetilde{\approx}$ & 0 & $\hat{\alpha}$ & 0 & 0 & 0 & $\infty$ \\
\hline & 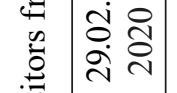 & 0 & in & $\bar{\sigma}$ & 0 & $\hat{\sigma}$ & F & $N$ & 0 & $\widetilde{N}$ \\
\hline & 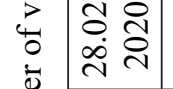 & $\sim$ & $\stackrel{\infty}{\varrho}$ & 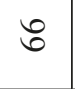 & 0 & ฉ & $\stackrel{2}{2}$ & 0 & 0 & 0 \\
\hline 䓂 & 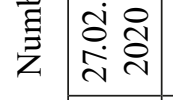 & 0 & $\widetilde{\sigma}$ & $\cong$ & 0 & $\stackrel{\infty}{0}$ & ले & 0 & 0 & 0 \\
\hline$\sum_{\infty}^{n}$ & 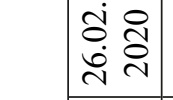 & 0 & $\stackrel{\infty}{\oplus}$ & $\cong$ & 0 & 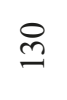 & $\ddot{m}$ & 0 & 0 & 0 \\
\hline & 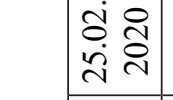 & 0 & ๙ & సి & 0 & F & $ㅇ$ & 0 & 0 & $\stackrel{+}{m}$ \\
\hline : & 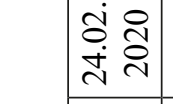 & 0 & $\mathbb{N}$ & $\stackrel{\Omega}{2}$ & 0 & లె & $\mathscr{f}$ & 0 & $\tilde{\sim}$ & 0 \\
\hline $\begin{array}{l}\stackrel{y}{N} \\
m \\
m\end{array}$ & 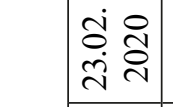 & 0 & $\stackrel{+}{m}$ & $\nabla$ & 0 & $\overrightarrow{\widetilde{N}}$ & ㄱ & $\sim$ & 0 & 0 \\
\hline 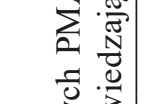 & 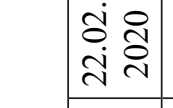 & 0 & $\tilde{\Xi}$ & ฉ & 0 & in & fo & 0 & 0 & 0 \\
\hline 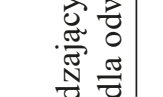 & 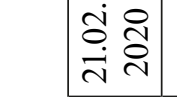 & 0 & $\stackrel{\beth}{\beth}$ & $\stackrel{ \pm}{I}$ & 0 & $\underset{⿱}{ \pm}$ & $\stackrel{\infty}{+}$ & - & 0 & 0 \\
\hline 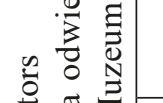 & 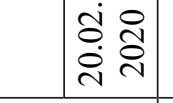 & 0 & $\stackrel{\text { }}{-}$ & $\stackrel{\sim}{\sim}$ & 0 & $\underset{\sim}{\approx}$ & రె & $n$ & 0 & $\sim$ \\
\hline 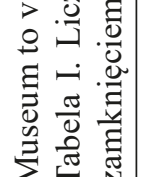 & $\begin{array}{l}\vec{E} \\
\text { 音 }\end{array}$ & 节 & 造 & 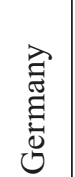 & $\begin{array}{l}00 \\
\overline{0} \\
\frac{0}{4} \\
00 \\
0 \\
0\end{array}$ & $\frac{\lambda}{\Xi}$ & $\begin{array}{l}\text { : } \\
\text { : } \\
\text { 壳 }\end{array}$ & 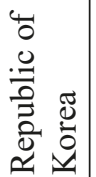 & 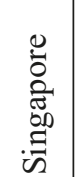 & 菢 \\
\hline
\end{tabular}


adapting the rules of operation of the Museum, adequately to the level of danger.

In the beginning, an Announcement was prepared. It was made available to all employees via the internal Internet network. It contained information on the prevention of SARS-CoV-2 coronavirus infections, the need to wash and disinfect hands, and to keep a safe distance from the interlocutor. The content of the Announcement indicated that employees should limit movement at the Museum buildings (limitation of personal contacts and restriction of access to the Library, the Collections Department and the Archives, were introduced) and interpersonal communication by telephone or e-mail were recommended. While moving between two parts of the A-BSM (Auschwitz I and Auschwitz II-Brzezinka), it was recommended for employees to use their own transport or the one specially separated for educators or employees. The details and precise steps to follow for employees with disturbing symptoms, that may indicate COVID-19, were also provided. The Announcement emphasised the seriousness of the epidemic and the need for employees to comply with the rules of microbiological safety in the first phase of the epidemic. A special message was also sent to heads of departments to oblige their employees to report their own or their family members' presence in the regions threatened by the coronavirus during the last 14 days. If such situation occured, the employee could be ordered to work remotely (at home). This aimed at limiting spreading of the coronavirus between colleagues.

On 27th February 2020 an information was posted on the website of the Museum, in which travel agencies were asked to refrain organising visits to the A-BSM from places at high risk of SARS-CoV-2 coronavirus infections. As a result of publishing this information, the attendance has slightly decreased, as can be seen in fig. 1.

After that, on 28th February 2020, admission to the grounds of the A-BSM without an educator was forbidden. Owing to this, all the visitors were under the care of educators, so it was definitely easier to control and prevent people from entering unauthorised places, moving around the Museum on their own and behaving in a way that would contribute to spreading of the coronavirus.

In the next stage, the Expert Team carried out a detailed analysis of potential threat in various places at the Museum and divided rooms into public spaces and spaces accessible only for staff. The rooms, that have been defined as public areas, were: the entrance room, where tickets are checked and pyrotechnic control is carried out, and toilets for visitors located throughout the Museum. These areas are enclosed spaces and there is the highest accumulation of członkowie zespołu będą spotykać się każdego dnia, aby opracować strategię działania. Zespół na bieżąco monitorował fazy rozprzestrzeniania się koronawirusa na świecie i w Polsce oraz dostosowywał zasady pracy Muzeum adekwatnie do poziomu zagrożenia.

W pierwszym etapie przygotowano Komunikat, który został udostępniony pracownikom poprzez wewnętrzną sieć internetową. Zawarto w nim informacje na temat profilaktyki zakażeń koronawirusem SARSCoV-2, konieczności mycia i dezynfekcji rąk oraz zachowanie bezpiecznej odległości względem rozmówcy. Treść komunikatu wskazywała, iż pracownicy powinni ograniczyć przemieszczanie się po budynkach Muzeum (wprowadzono ograniczenie kontaktu osobistego oraz dostępu do Biblioteki, Działu Zbiorów oraz Archiwum) i zarekomendowano komunikację interpersonalną drogą telefoniczną lub elektroniczną. Przy przemieszczaniu się pomiędzy dwiema częściami PMA-B (Auschwitz I i Auschwitz II-Brzezinka) zalecono korzystanie z własnego transportu lub specjalnie wyodrębnionego dla edukatorów lub pracowników. Podano również szczegóły i precyzyjne wytyczne, jakich muszą przestrzegać pracownicy z niepokojącymi objawami mogącymi wskazywać na COVID-19. Komunikat ten przedstawił powagę sytuacji związanej z epidemią oraz konieczność przestrzegania zasad bezpieczeństwa mikrobiologicznego przez pracowników już w pierwszej fazie epidemii. Wystosowano również specjalny komunikat do Kierowników działów, aby zobligowali swoich pracowników do zgłaszania faktu przebywania ich samych lub członków ich rodzin na terenach zagrożonych koronawirusem w okresie ostatnich 14 dni. W przypadku wystąpienia takiej sytuacji, pracownikowi mogła być powierzona praca zdalna (w domu). Miało to na celu ograniczenie możliwości rozprzestrzeniania się koronawirusa pomiędzy współpracownikami.

Jednocześnie, dnia 27.02.2020 na stronie internetowej zamieszczono informację dla biur podróży o zaniechaniu organizacji wizyt do PMA-B z miejsc zagrożonych występowaniem koronawirusa SARSCoV-2. Na skutek przekazania tej informacji frekwencja uległa nieznacznemu zmniejszeniu, co widać na ryc. 1.

Następnie, dnia 28.02.2020 wprowadzono zakaz zwiedzania indywidualnego, bez Edukatora. Dzięki temu wszystkie grupy były pod opieką edukatora, zatem zdecydowanie łatwiej było kontrolować i zapobiegać, aby ludzie nie wchodzili w miejsca niedozwolone i nie przemieszczali się samowolnie po terenie $\mathrm{Mu}-$ zeum oraz nie zachowywali się w sposób ułatwiający rozprzestrzenianie wirusa.

W kolejnym etapie Zespół Ekspercki przeprowadził szczegółową analizę obszarów potencjalnego zagrożenia oraz dokonał podziału pomieszczeń na 
people, so the most restrictive methods of protection of employee were applied there. Disinfection by fumigation (spreading a dry-mist of $6 \%$ boosted hydrogen peroxide) of the entire volume of all public rooms, at least once a day, after leaving all visitors, was introduced. This method of decontamination ensured the microbiological cleanliness of the surfaces and air in the disinfected rooms. Additionally, contactless hand disinfection devices (spraying the mixture of ethanol (78\%), isopropanol (10\%) and biphenyl-2-ol (0.1\%)) for visitors and employees were placed in public spaces to limit spreading of the coronavirus by touching infected surfaces. In the case of toilets for people visiting the A-BSM, disinfection was recommended without the presence of visitors. On the other hand, the remaining enclosed spaces (conservation laboratories, offices and social facilities) were classified as available only to personnel and the precautions were also taken in them. The Director's decree introduced a detailed operating Instruction for all employees moving around the Museum. The Instruction included not only information contained in an earlier Announcement, but also extended and clarified ones. The rooms available only to employees were equipped with disinfectants (based on ethanol) and regular decontamination by fumigation was planned. Moreover, all blocks and barracks open to the public were considered the places in which the coronavirus could also spread among people, but frequent disinfection was not possible due to the historical nature of these rooms. In this case, to minimalise the risk of the coronavirus infections, changes in the way of visiting the Memorial Site were introduced. The visiting route in some buildings was changed, e.g., by using side exits, passing some rooms and undergrounds, what ensured the movement in one direction without crossing of the routs. For study tour groups, it was recommended to use national exhibitions to a greater extent, avoiding staying in blocks, where the permanent exhibition is exposed. The website of the Museum was regularly updated with information concerning all changes. Additionally, educators were advised to limit as much as possible commentaries inside the buildings and pass most of the narrative outside. Furthermore, contactless hand disinfection devices (Fig. 2) and special trash cans with bags intended for infectious materials such as used masks, gloves and other potentially contaminated personal protective equipment were made available at all entrances to the Museum.

Simultaneously, the Expert Team identified the groups of people working at the Museum, which were most exposed to a contact with visitors and, as a consequence, at the highest risk of SARSCoV-2 coronavirus infection. Among these people there were: educators, who give tours, personnel of przestrzenie ogólnodostępne oraz dostępne tylko dla personelu. Pomieszczenia, które zostały określone jako ogólnodostępne to: pomieszczenie wejściowe, w którym dokonuje się sprawdzenia biletów i kontrolę pirotechniczną oraz toalety dla odwiedzających rozlokowane na terenie całego Muzeum. W pomieszczeniach ogólnodostępnych jest największa kumulacja osób, dodatkowo są to pomieszczenia zamknięte, więc zastosowano $\mathrm{w}$ nich najbardziej restrykcyjne metody ochrony pracowników. Wprowadzono dezynfekcję fumigacyjną (zamgławianie 6\% plazmowanym nadtlenkiem wodoru) całej objętości wszystkich wyznaczonych pomieszczeń minimum jeden raz w ciągu dnia po opuszczeniu Muzeum przez wszystkich odwiedzających. Taki sposób odkażania zapewnił czystość mikrobiologiczną powierzchni oraz powietrza w dezynfekowanych miejscach. Ponadto w tych pomieszczeniach umieszczono aparaty do bezdotykowej dezynfekcji rąk (rozpylające mieszaninę etanolu (78\%), izopropanolu (10\%) i bisfenyl-2-olu (0.1\%)) dla odwiedzających oraz dla pracowników w celu ograniczenia rozprzestrzeniania się koronawirusa poprzez dotykanie zainfekowanych powierzchni. W przypad$\mathrm{ku}$ toalet dla odwiedzających polecono wykonywanie czynności dezynfekujących bez obecności zwiedzających. Natomiast pozostałe pomieszczenia zamknięte (pracownie konserwatorskie, biura, zaplecza socjalne) sklasyfikowano jako dostępne tylko dla personelu i również w nich wprowadzono środki ostrożności. Wprowadzono zarządzeniem Dyrektora szczegółową instrukcję postępowania dla wszystkich pracowników poruszających się po terenie Muzeum. Instrukcja obejmowała informacje znajdujące się we wcześniejszym Komunikacie, ale rozszerzone oraz doprecyzowane. Pomieszczenia dostępne tylko dla pracowników wyposażono w środki dezynfekcyjne (na bazie etanolu) i zaplanowano w nich regularną dekontaminację fumigacyjną. Ponadto, wszystkie bloki i baraki udostępnione do zwiedzania uznano za przestrzenie, w których również może rozprzestrzeniać się koronawirus pomiędzy ludźmi, jednak nie jest możliwa ich częsta dezynfekcja, z uwagi na zabytkowy charakter tych pomieszczeń. W tym przypadku, aby zminimalizować rozprzestrzenianie się wirusa wprowadzono zmiany w sposobie zwiedzania Miejsca Pamięci. Zmieniono trasę zwiedzania niektórych bloków np. wykorzystując boczne wyjścia, pomijanie niektórych sal i podziemi, co zapewniło ruch w jednym kierunku i nie krzyżowanie się dróg. W przypadku oprowadzania studyjnego zalecono wykorzystywanie w większym stopniu wystaw narodowych, unikając przebywania w blokach, gdzie eksponowana jest wystawa stała. O wszystkich zmianach informowano na bieżąco na stronie internetowej Muzeum. Ponadto Edukatorom zalecono maksymalne ograniczenie komentarza w bu- 


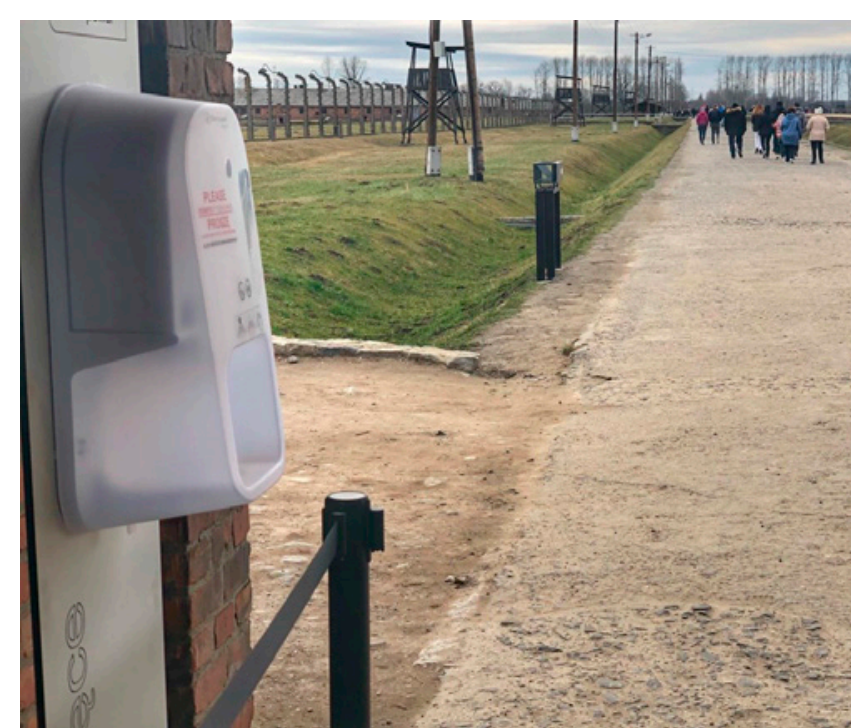

Fig. 2. Device for contactless hand disinfection located at the entrance to the Auschwitz II-Brzezinka site (author: Bartosz Bartyzel)

Ryc. 2. Aparat do bezdotykowej dezynfekcji rąk umieszczony przy wejściu na teren Auschwitz II - Brzezinka (autor zdjęcia: Bartosz Bartyzel)

the Visitor Service, who check and sell tickets and dispense sound equipment for visitors, employees responsible for maintaining cleanliness throughout the Museum and also staff of the Museum Security, who carry out pyrotechnic control of all entering people. Therefore, biosecurity Procedures dedicated specifically to these groups of employees were first developed. Guidelines were prepared both for normal work (without a suspicion of a person infected with the coronavirus) and for work in the event of a presence of a person suspected to be infected with the coronavirus. The Procedure intended for educators included recommendations to: wear a protective face shield, keep a minimum distance of 2 meters from visitors and inform them before starting the tour that all biosafety rules applicable in the A-BSM should be respected. All educators were obliged to observe the behavior of visitors, and in the event of identifying a person who has symptoms of COVID-19 (cough, shortness of breath and increased body temperature) to report such situation to the Museum Security personnel. The Procedure for the staff of Visitor Service included the recommendation of using disposable face masks and gloves while contacting visitors, disinfecting the sound equipment after each use, and not engaging in helping visitors to put on the sound equipment. People responsible for maintaining cleanliness at the Museum were advised to carry out all activities with protective gloves, disinfect door handles and light switches more often than before, and separate cleaning agents and working tools used to clean the space used by employees, from those used in the public spaces. dynkach i przekazywanie większości narracji na zewnątrz. Dodatkowo przed wszystkimi wejściami na teren Muzeum, zostały udostępnione aparaty do bezdotykowej dezynfekcji rąk (Ryc. 2) i kosze z workami przeznaczonymi na materiał zakaźny, do których można było wrzucać zużyte maseczki, rękawice i inne potencjalnie skażone elementy ochrony osobistej.

W kolejnym etapie prac Zespołu Eksperckiego, określono grupy pracowników najbardziej narażonych na kontakt z odwiedzającymi, a w konsekwencji najbardziej zagrożonych zakażeniem koronawirusem SARS-CoV-2. Wśród tych osób znaleźli się: Edukatorzy, którzy oprowadzają odwiedzających, pracownicy Obsługi Odwiedzających, którzy kontrolują i sprzedają bilety oraz wydają odwiedzającym sprzęt nagłaśniający, pracownicy odpowiadający za utrzymanie czystości na całym terenie Muzeum oraz pracownicy Straży Muzealnej, którzy przeprowadzają kontrolę pirotechniczną wszystkich wchodzących osób. Zatem w pierwszej kolejności opracowano procedury bezpieczeństwa biologicznego dedykowane specjalnie dla tych grup pracowników. Opracowano wytyczne postępowania w trybie normalnej pracy (bez podejrzeń o obecność osoby zakażonej koronawirusem) oraz pracy w sytuacji pojawienia się osoby z podejrzeniem zakażenia. Procedura przeznaczona dla Edukatorów obejmowała zalecenia, aby: stosować przyłbice, zachować odstęp minimum 2 metry od oprowadzanych osób, a przed rozpoczęciem zwiedzania poinformować ich o konieczności zachowania wszystkich zasad bezpieczeństwa obowiązujących w PMA-B. Edukatorzy byli zobligowani do obserwacji zachowań odwiedzających, a w przypadku zidentyfikowania osoby, która ma objawy choroby COVID-19 (kaszel, duszność oraz zwiększona ciepłota ciała), konieczność zgłoszenia zaistnienia takiej sytuacji pracownikowi Straży Muzealnej. Procedura dla pracowników Obsługi Odwiedzających obejmowała zalecenie używania jednorazowych maseczek oraz rękawic ochronnych przy kontakcie z odwiedzającymi, dezynfekowania sprzętu nagłaśniającego każdorazowo po każdej osobie oraz nieangażowania się w pomoc w zakładaniu sprzętu nagłaśniającego odwiedzającym. Osobom odpowiadającym za utrzymanie czystości w Muzeum zalecono, aby wszystkie czynności wykonywać w rękawicach ochronnych, częściej niż dotychczas dezynfekować klamki i włączniki światła, a także oddzielić środki czystości i narzędzia pracy wykorzystywane do sprzątania przestrzeni użytkowanej przez pracowników od tych, które są stosowane w przestrzeniach ogólnodostępnych. Zgodnie z procedurą, pracownicy Straży Muzealnej przebywający w pomieszczeniach ogólnodostępnych, zobligowani zostali do zakładania jednorazowych maseczek, rękawic, gogli i przyłbic, a także do zmiany odzieży wierzchniej po zakończeniu pracy 
According to the Procedure, the Museum Security personnel staying in public areas was obliged to put on disposable face masks, gloves, goggles and face shields. They were also supposed to change outerwear after finishing work and subject it to disinfection and washing. For this purpose, employees were equipped with additional cabinets, which ensured that dirty and clean clothes did not mix with each other. The Museum Security employees were also given instructions how to deal with a person who has symptoms of COVID-19. After accepting a notification of intervention, an employee of Museum Security equipped with a set of 3 masks and 3 pairs of gloves should go to the location of the person suspected of the coronavirus infection. Next, the employee ought to secure himself or herself, then give personal protective equipment to the person reporting malaise and the person reporting this intervention. Next, the temperature measurement should be taken and interview should be done with keeping a safe distance. Depending on the information obtained from the person with symptoms, the employee was required to report the situation to the Polish Sanitary Inspection (if the temperature exceeded 38 ${ }^{\circ} \mathrm{C}$ and the person confirmed that he or she was in the region where the coronavirus threat occurred or had contact with a person who was in such region). If the temperature did not exceed $38{ }^{\circ} \mathrm{C}$ and the person did not confirm the fact of being in the region threatened by the coronavirus and contact with people staying in such region, the employee of the Museum Security could make it possible to continue the tour (for visitors) or work (for personnel).

The cooperation with the Polish Sanitary Inspection, which is formally responsible for supervising this type of activities in Poland, was very important at all stages of the work of the Expert Team. All implemented Procedures were accepted by this Inspection and communicated to the Polish Chief Sanitary Inspector and the Ministry of Culture and Heritage, to which the A-BSM is subordinated directly.

At last, on 12th March 2020, the Museum was closed for visitors in accordance with the announcement of the Ministry of Culture and Heritage and by the act on special solutions related to the prevention, counteraction and eradication of COVID-19, other infectious diseases and crisis situations caused by them of 2nd March 2020 (12). However, the personnel of the Museum, including members of the Expert Team, continued their work. After a few days, a rule was introduced, according to which employees were obliged, if possible, to work remotely or have overdue holidays.

The presence of many employees at the Museum during the epidemic was inevitable, because they ensure continuity of the Museum operation and to i poddawaniu jej dezynfekcji oraz praniu. W tym celu pracownicy zostali doposażeni w dodatkowe szafki, które zapewniły, iż odzież brudna i czysta nie mieszały się ze sobą. Pracownikom Straży Muzealnej przekazano również instrukcje postępowania z osobą, która wykazywałaby objawy COVID-19. Po zgłoszeniu interwencji, pracownik Straży Muzealnej wyposażony w zestaw trzech maseczek i trzech par rękawic powinien udać się na miejsce i zabezpieczyć siebie, następnie podać środki ochrony osobistej osobie zgłaszającej złe samopoczucie oraz osobie zgłaszającej interwencję. Zachowując bezpieczny odstęp powinien dokonać pomiaru temperatury i przeprowadzić wywiad. W zależności od uzyskanej informacji od osoby z objawami, pracownik miał obowiązek zgłoszenia zaistniałej sytuacji do Inspekcji Sanitarnej (jeśli temperatura przekroczyła $38^{\circ} \mathrm{C}$ i odwiedzający potwierdził, że był na terenie na którym występowało zagrożenie koronawirusem lub miał kontakt $\mathrm{z}$ osobą, która była na takim terenie). Jeśli temperatura nie przekroczyła $38^{\circ} \mathrm{C}$ i osoba nie potwierdziła faktu przebywania na terenie zagrożonym koronawirusem oraz kontaktu z osobami przebywającymi na takim terenie, pracownik Straży Muzealnej mógł umożliwić kontynuację zwiedzania (dla odwiedzających) lub pracy (dla personelu).

Na każdym etapie prac Zespołu Eksperckiego bardzo istotna była współpraca z Państwową Inspekcją Sanitarną, która formalnie odpowiedzialna jest w Polsce za nadzorowanie tego typu działań. Wszystkie zastosowane procedury były akceptowane przez tę Inspekcję oraz podawane do wiadomości Głównemu Inspektorowi Sanitarnemu w Polsce oraz Ministrowi Kultury i Dziedzictwa Narodowego, któremu PMA-B podlega bezpośrednio.

Ostatecznie, dnia 12.03.2020 Muzeum zostało zamknięte dla odwiedzających zgodnie z Komunikatem Ministra Kultury i Dziedzictwa Narodowego oraz Ustawą o szczególnych rozwiązaniach związanych z zapobieganiem, przeciwdziałaniem i zwalczaniem COVID-19, innych chorób zakaźnych oraz wywołanych nimi sytuacji kryzysowych z dnia 2 marca 2020 (12). Jednak pracownicy obsługujący Muzeum nadal świadczyli pracę, w tym członkowie Zespołu Eksperckiego. Po kilku dniach takiego funkcjonowania wprowadzono jednak zasadę, zgodnie z którą pracownicy byli zobligowani w miarę możliwości do pracy zdalnej lub wykorzystania zaległych urlopów.

$\mathrm{W}$ celu zapewnienia ciągłości funkcjonowania oraz zabezpieczenia mienia i obiektów zabytkowych w Muzeum, w trakcie trwania epidemii niezbędna była obecność wielu pracowników na terenie Muzeum. Każdy z nich zobowiązany był do przestrzegania postanowień opracowanych procedur. Procedury były dedykowane poszczególnym grupom pracowników, między innymi: pracownikom nadzorującym zbiory, 
secure the property and historical objects belonging to the Museum. Each of them was obliged to comply with the provisions of the newly developed and implemented Procedures. The Procedures were dedicated to particular groups of employees, among others: supervising the collections, archival materials and technical condition of historical buildings, supervising technical installations, removing failures and working in offices. Each of the Procedures required employees to declare their willingness to enter the Museum in advance. Entrances were carried out in a way limiting contact between people. Everyone had to disinfected hands and keys, and if he or she worked in a team of two or more people, the person had to put on a disposable face mask and gloves. Employees could only move in designated places. An exceptional situation would be a failure, during which employees would not be able to keep a safe distance between one another. In such situation, everyone should put on protective goggles and clothing (apart from a mask and gloves). The Procedures also included information for employees of external companies, who carried out building works necessary to maintain the stability of structures under construction. All building sites were separated from other spaces at the Museum. The employees of the A-BSM did not have the possibility of direct verbal communication with employees of external companies. External companies could enter the Museum only with their own cars and move only within the designated building sites. The condition for the continuation of work by external companies was to have their own sanitary-hygienic and social facilities, which had to be located at the construction site. Each employee of an external company had to sign a declaration on applying all provisions of the A-BSM Procedures, while entering the Museum.

All employees of the A-BSM, regardless of whether they rendered work during the epidemic or remained outside the Museum, received instructions what to do in case of suspected SARS-CoV-2 coronavirus infection. Continuous education was intended to raise awareness and promote appropriate behavior among employees and their families. The social responsibility that everyone takes for limiting the spread of the coronavirus and stopping the pandemic was emphasised.

To prepare for reopening of the Museum for visitors, the Expert Team developed a special Procedure and adapted the infrastructure. The number of visitors was limited to 400 persons per hour (in hours when visitors are obliged to visit with educators) and 100 persons per hour (in hours without such an obligation) and visiting hours to 9 per day. Additionally, contact details were obtained from all visitors to facilitate cooperation with the Sanitary archiwalia i stan techniczny historycznych budynków, nadzorującym instalacje, usuwającym awarie oraz pracownikom biurowym. Każda z procedur wymagała od pracowników wcześniejszego zgłaszania chęci wejścia na teren Muzeum. Wejścia realizowano w taki sposób, żeby ograniczyć kontakt osób wchodzących. Każdy dezynfekował ręce, klucze i jeżeli pracował w zespole dwu i więcej osobowym, musiał założyć jednorazową maseczkę i rękawice ochronne. Pracownicy mogli się poruszać tylko w wyznaczonych miejscach. Wyjątkową sytuacją byłaby awaria, podczas której pracownicy nie mieliby możliwości zachowania bezpiecznego odstępu między sobą. W takiej sytuacji każdy powinien założyć kombinezon i gogle ochronne (oprócz maseczki i rękawic). W procedurach zawarto również informacje dla pracowników firm zewnętrznych, którzy realizowali prace budowlane niezbędne do utrzymania stabilności konstrukcji będących w trakcie budowy. Wszystkie place budowy zostały oddzielone od innych przestrzeni Muzeum. Pracownicy PMA-B nie mieli możliwości bezpośredniej komunikacji werbalnej z pracownikami firm zewnętrznych. Firmy zewnętrzne mogły wjeżdżać na teren Muzeum tylko swoimi samochodami i przemieszczać się tylko w obrębie wyznaczonych placów budów. Warunkiem kontynuowania pracy przez firmy zewnętrzne było posiadanie własnego zaplecza sanitarno-higienicznego oraz socjalnego, które musiało być zlokalizowane na terenie placu budowy. Każdy pracownik firmy zewnętrznej wchodząc na teren Muzeum musiał podpisać oświadczenie, iż będzie stosować wszystkie postanowienia procedur PMA-B.

Wszyscy pracownicy, niezależnie od tego czy świadczyli pracę w trakcie epidemii, czy pozostawali poza Muzeum, otrzymywali instrukcje postępowania w sytuacji podejrzenia zagrożenia koronawirusem SARS-CoV-2. Ciągłe edukowanie miało na celu zwiększanie świadomości i propagowanie właściwych zachowań wśród pracowników oraz członków ich rodzin. Podkreślano odpowiedzialność społeczną jaką wszyscy ponoszą za ograniczenie rozprzestrzeniania się tego wirusa i zahamowanie pandemii.

W ramach przygotowania Muzeum do ponownego otwarcia dla odwiedzających, Zespół Ekspertów opracował specjalną procedurę i dostosował infrastrukturę. Ograniczono liczbę odwiedzających do 400 osób/ godzinę (w godzinach, w których jest obowiązek zwiedzania z edukatorami) i 100 osób/godzinę (w godzinach, w których nie ma takiego obowiązku) i godzin zwiedzania do 9/dzień. Dodatkowo pozyskiwano dane kontaktowe od wszystkich odwiedzających w celu ułatwienia współpracy z inspekcją sanitarną w sytuacji wystąpienia koronawirusa u któregokolwiek z uczestników zwiedzania. Zorganizowano przejazd z Auschwitz I do Auschwitz II-Brzezinka z zachowaniem 
Inspection in the event of coronavirus occurrence in any of the tour participants. A transfer from Auschwitz I to Auschwitz II-Brzezinka was organised in such a way to maintain the security procedures in force of the Republic of Poland regarding public transport. It was ordered that visitors entering the Museum must have their mouths and nose covered, and are obliged to disinfect themselves in a sanitation gate installed at the entrance to the Museum (Fig. 3). This gate model was created by WAAM company in close cooperation with scientists from the Silesian University of Technology in Gliwice and A-BSM. The model was especially designed to match the needs of the Museums and adapted to people with physical disabilities. The disinfectant used is $2 \%$ hydrogen peroxide in the form of mist. The device is fully automatic and equipped with regulation systems and developed light and sound signaling systems, which inform about the appropriate movement of persons inside the chamber, what increases the contact efficiency of user and disinfectant. The device and its constructors won one of the prizes in the international Healing Solutions for Tourism Challenge, a competition for innovative ideas to mitigate negative impact of the epidemic on tourism organised by World Tourist Organization and WHO. It is mandatory that every visitor will also have to undergo remote contactless temperature measurement.

\section{CONCLUSIONS}

This article was written to provide information, on how to deal with the pandemic caused by SARS-CoV-2 coronavirus in institutions taking care of cultural heritage before and after closing for visitors. At the same time, it may be used as a guide for proceedings after reopening of the Museum for visitors, when the protection of employees against this and other pathogenic microorganisms. During the SARS-CoV-2 coronavirus epidemic, when the Museum was open to visitors, many employees had contact with thousands of people from all around the world, including regions where outbreaks of the coronavirus infections were reported, e.g., China, France, Germany, Hong Kong, Italy, Japan, Republic of Korea, Singapore and Taiwan. In retrospect (i.e. more than 21 days from the closing of the Museum for visitors), it can be stated that the correct decisions of the Directorate and the work of the Expert Team, and thus actions taken very early to ensure the safety of employees, made that none of the employees got infected with SARS-CoV-2 coronavirus or came down with COVID-19.

Permanent supervision and protection of the employees against infections after closing the Museum for visitors, developing and implementing subsequent Procedures for people, whose presence at the Museum

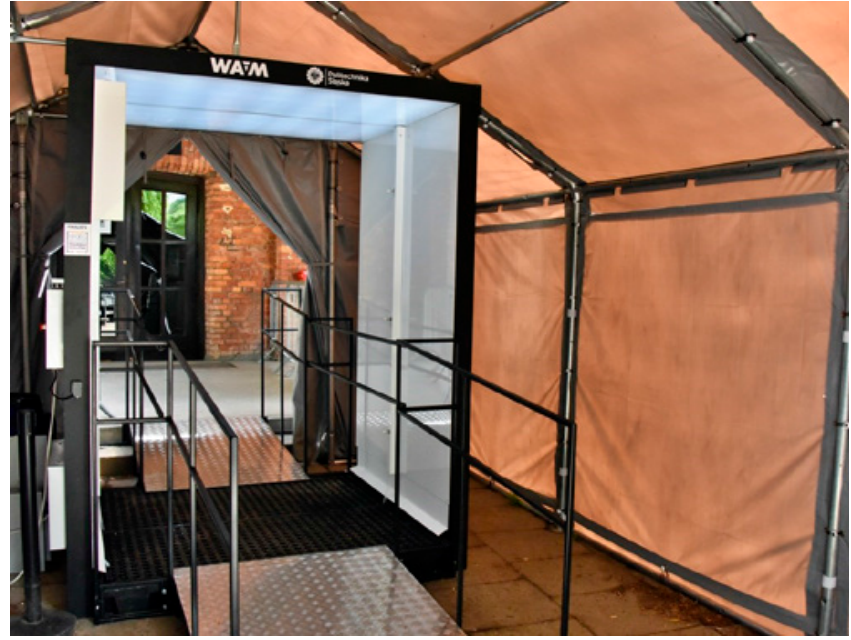

Fig. 3. Disinfection gate located at the entrance to the Auschwitz I site (author: Bartosz Bartyzel)

Ryc. 3. Bramka dezynfekcyjna umieszczona przy wejściu na teren Auschwitz I (autor zdjęcia: Bartosz Bartyzel)

procedur bezpieczeństwa obowiązujących na terenie Rzeczpospolitej Polskiej dotyczących środków publicznego transportu zbiorowego. Zarządzono, iż odwiedzający wchodzący na teren Muzeum muszą mieć zasłonięte usta i nos oraz są zobowiązani do dezynfekcji w bramce dezynfekcyjnej zainstalowanej przy wejściu do Muzeum (Ryc. 3). Ten model bramki został opracowany przez firmę WAAM w ścisłej współpracy z naukowcami z Politechniki Śląskiej w Gliwicach oraz z PMA-B. Ten model został indywidualnie zaprojektowany tak, aby spełniać potrzeby Muzeum oraz dostosowany do osób z niepełnosprawnością ruchową. Zastosowanym środkiem dezynfekcyjnym jest $2 \%$ nadtlenek wodoru w formie mgły. Urządzenie jest $\mathrm{w}$ pełni zautomatyzowane i wyposażone w systemy regulacji oraz zaawansowane systemy sygnalizacji świetlnej i dźwiękowej, które informują o odpowiednim ruchu osób w komorze, co zwiększa efektywność kontaktu użytkownika i środka dezynfekującego. Urządzenie i jego konstruktorzy wygrali jedną z nagród w międzynarodowym konkursie na innowacyjne pomysły mające na celu złagodzenie negatywnego wpływu epidemii na turystykę Healing Solutions for Tourism Challenge, organizowanym przez Światową Organizację Turystyczną i WHO. Obowiązkowo każdy odwiedzający będzie musiał również poddać się zdalnemu bezdotykowemu pomiarowi temperatury.

\section{WNIOSKI}

Niniejszy artykuł napisano w celu przekazania informacji, w jaki sposób można postępować w sytuacji pandemii spowodowanej koronawirusem SARSCoV-2 w jednostkach dbających o dziedzictwo kulturowe przed i po zamknięciu dla odwiedzających. Zara- 
was necessary to ensure continuity of the A-BSM operation and safety of facilities, resulted also in good effect.

\section{REFERENCES}

1. Auschwitz Muzeum and Memorial 2019 Report. http://auschwitz.org/download/gfx/auschwitz/ en/defaultstronaopisowa/358/15/1/auschwitz raport 2019.pdf

2. WHO, 21.01.2020. Novel Coronavirus (2019$\mathrm{nCoV})$ Situation Report no. 1. https://www. who.int/docs/default-source/coronaviruse/ situation-reports/20200121-sitrep-1-2019-ncov. pdf?sfvrsn=20a99c10 4

3. WHO, 25.01.2020. Novel Coronavirus (2019$\mathrm{nCoV}$ ) Situation Report no. 5. https://www. who.int/docs/default-source/coronaviruse/ situation-reports/20200125-sitrep-5-2019-ncov. pdf?sfvrsn $=429 \mathrm{~b} 143 \mathrm{~d} \quad 8$

4. WHO, 28.01.2020. Novel Coronavirus (2019$\mathrm{nCoV}$ ) Situation Report no. 8. https://www. who.int/docs/default-source/coronaviruse/ situation-reports/20200128-sitrep-8-ncov-cleared. pdf?sfvrsn $=8 \mathrm{~b} 671 \mathrm{ce} 5 \_2$

5. WHO, 27.02.2020. Coronavirus disease 2019 (COVID-19) Situation Report no. 38. https:// www.who.int/docs/default-source/coronaviruse/ situation-reports/20200227-sitrep-38-covid-19. pdf?sfvrsn=2db7a09b 4

6. WHO, 11.03.2020. Coronavirus disease 2019 (COVID-19) Situation Report no. 51. https:// www.who.int/docs/default-source/coronaviruse/ situation-reports/20200311-sitrep-51-covid-19. pdf?sfvrsn=1ba62e57_10

7. GIS, 20.02.2020. Komunikat dla podróżujących (nr 28), 20 lutego 2020 r. https://gis.gov.pl/aktualnosci/ komunikat-dla-podrozujacych-nr-28-20-lutego2020-r-opracowano-na-podstawie-danych-ecdcoraz-who/

8. GIS, 21.02.2020. Komunikat dla podróżujących (nr 29), 21 lutego 2020 r. https://gis.gov.pl/aktualnosci/ komunikat-dla-podrozujacych-nr-29-21-lutego2020-r-opracowano-na-podstawie-danych-ecdcoraz-who/

9. GIS, 23.02.2020. Komunikat dla podróżujących (nr 30), 23 lutego $2020 \mathrm{r}$. https://gis.gov.pl/aktualnosci/ komunikat-dla-podrozujacych-nr-30-23-lutego2020-r-opracowano-na-podstawie-danych-ecdcoraz-who/

10. GIS, 28.02.2020. Komunikat dla podróżujących (nr 35) Warszawa, 28 lutego 2020 r. https://gis.gov. pl/aktualnosci/komunikat-dla-podrozujacych-nr- zem może posłużyć jako wskazówka do postępowania po otwarciu Muzeum dla odwiedzających, kiedy przez długi czas jeszcze będzie konieczność zabezpieczania pracowników przed tym i innymi patogennymi drobnoustrojami. W trakcie epidemii wywołanej koronawirusem SARS-CoV-2, kiedy Muzeum było otwarte dla odwiedzających, wielu pracowników miało kontakt z tysiącami osób z całego świata, w tym z rejonów, w których były ogniska zakażeń, tj. Chiny, Francja, Niemcy, Hong Kong, Włochy, Japonia, Republika Korei, Singapur i Tajwan. Z perspektywy czasu (tj. ponad 21 dni od zamknięcia Muzeum dla odwiedzających) można stwierdzić, iż właściwe decyzje Dyrekcji i praca Zespołu Eksperckiego, a co za tym idzie, bardzo wcześnie podjęte działania w celu zapewnienia bezpieczeństwa pracownikom, spowodowały, iż żaden z pracowników nie uległ zakażeniu SARS-CoV-2 oraz nie zachorował na COVID-19. Stały nadzór oraz zapewnienie ochrony przed zakazeniem pracownikom po zamknięciu PMA-B dla odwiedzających, opracowywanie oraz wdrażanie kolejnych procedur dla osób, które muszą pracować na terenie Muzeum w celu zapewnienia ciągłości funkcjonowania oraz zapewnienia bezpieczeństwa obiektom, przyniosło również dobre rezultaty.

35-warszawa-28-lutego-2020-r-opracowano-napodstawie-danych-ecdc-oraz-who/

11. GIS, 06.03.2020. Komunikat dla podróżujących nr 42 Warszawa, 6 marca 2020 r. https://gis.gov. pl/aktualnosci/komunikat-dla-podrozujacych-nr42-warszawa-6-marca-2020-r-opracowano-napodstawie-danych-who/

12. Dz. U. RP, 7 marca 2020, poz. 374. Ustawa o szczególnych rozwiązaniach związanych $\mathrm{z}$ zapobieganiem, przeciwdziałaniem i zwalczaniem COVID-19, innych chorób zakaźnych oraz wywołanych nimi sytuacji kryzysowych.

Received:2.06.2020

Accepted for publication:

Otrzymano: 2.06.2020 r.

Zaakceptowano do publikacji:

Address for correspondence: Adres do korespondencji:

Dorota Rybitwa,

Auschwitz-Birkenau State Museum,

Więźniów Oświęcimia 20,

32-603 Oświęcim, Poland,

dorota.rybitwa@auschwitz.org,

+48338448170 